\title{
Organization of ribosomal RNA genes from the footrot pathogen Dichelobacter nodosus
}

\author{
Sharon La Fontaine $\nmid$ and Julian I. Rood \\ Author for correspondence: Julian I. Rood. Tel: +6139905 4825. Fax: +61399054811. \\ e-mail: julian.rood@med.monash.edu.au.
}

Department of Microbiology, Monash University, Clayton, Victoria 3168, Australia

\begin{abstract}
Southern hybridization analysis revealed that there were three rrn loci within the genome of Dichelobacter nodosus, the causative organism of ovine footrot. These loci ( $r r n A$, rrnB and $r r n C$ ) were isolated on recombinant lambda clones, and comprised 16S, 235 and 55 rRNA genes closely linked in that order. Sequence and primer extension analysis revealed the presence of putative genes encoding tRNAlle and tRNA ${ }^{\text {Ala }}$ within the 165-235 spacer region, as well as a number of potential regulatory features. These elements included a single promoter, which was mapped upstream of the 165 rRNA gene and which was similar to Escherichia coli consensus promoter sequences, an AT-rich upstream region, a GC-rich motif that may be involved in stringent control, leader and spacer antitermination sequences, sites for ribonuclease processing, and a putative factor-independent terminator sequence. Potential open reading frames (ORFs) were identified within the regions flanking the rrn loci, with identical copies of the $3^{\prime}$ terminal ORF present downstream of each rRNA operon. Determination of the complete sequence of the 55 rRNA gene, and derivation of the $5 S$ rRNA secondary structure, further substantiated the 165 rRNA-based placement of $D$. nodosus within the gamma division of the Proteobacteria.
\end{abstract}

Keywords: Dichelobacter nodosus, footrot, rrn operon, rRNA genes, phylogeny

\section{INTRODUCTION}

Since ribosomes constitute the translational machinery of the cell, ribosomal RNA (rRNA) is vital to cellular growth, function and survival. Consequently, the primary, secondary and tertiary structures of rRNA molecules have been highly conserved during evolution (Gutell, 1992). The organization of rRNA genes $(r r n)$ from bacteria representing several different phylogenetic groupings has been examined (Krawiec \& Riley, 1990; Menke et al., 1991). These studies have enabled comparisons to be made with respect to bacterial rrn gene organization and the sequence elements which govern the synthesis, regulation and processing of rRNA molecules, and have led to the suggestion that rrn organization may provide additional genetic evidence for the coherence of

\footnotetext{
†Present address: The Murdoch Institute, Royal Children's Hospital, Parkville, Victoria 3052, Australia.

Abbreviation: RNAP, RNA polymerase.

The GenBank accession numbers for the nucleotide sequence data reported in this paper are U26680, U26681, U26682, U26683 and U26684.
}

groupings defined on the basis of phylogenetic analyses (Menke et al., 1991).

The genes encoding the rRNA molecules of Escherichia coli have been most extensively characterized and are organized as transcriptional units, each with the gene order 16S-23S-5S (Jinks-Robertson \& Nomura, 1987; Srivastava \& Schlessinger, 1990). This order and linkage of rRNA genes is a common, though not universal, feature of bacterial $r r n$ organization (Krawiec \& Riley, 1990; Srivastava \& Schlessinger, 1990; Menke et al., 1991). Transcription of the seven E. coli rrn operons proceeds from multiple promoters which are differentially regulated, is subject to growth-rate and stringent control (Jinks-Robertson \& Nomura, 1987; Wagner, 1994), and is accompanied by antitermination mechanisms to prevent premature transcription termination (Berg et al., 1989). In addition, two classes of $16 \mathrm{~S}-23 \mathrm{~S}$ rRNA intergenic spacer regions exist, one carrying tRNA $A_{1}^{\text {Ile }}$ and $t R N A_{1}^{\text {Ala }}$ genes $(\operatorname{rrn} A, D$ and $H)$, and the other carrying a tRNA Glu gene ( $r r n B, C, E$ and $G$ ) (Jinks-Robertson \& Nomura, 1987). Additional 5S rRNA and/or tRNA genes are present at the distal end of some E. coli rrn operons. 
Dichelobacter nodosus is a member of the Cardiobacteriaceae (Dewhirst et al., 1990), and is the essential causative agent of ovine footrot (Stewart, 1989), a debilitating disease of sheep which continues to afflict the Australian sheep and wool industry. This bacterium is a slow-growing, fastidious, obligately anaerobic, Gram negative, rod-shaped organism, for which there is no system for genetic manipulation. Determination of the $D$. nodosus $16 \mathrm{~S}$ rRNA sequence led to the elucidation of its true phylogenetic status (Dewhirst et al., 1990; La Fontaine \& Rood, 1990), and to improved methods of detection using $16 \mathrm{~S}$ rDNAbased PCR analysis (La Fontaine et al., 1993). To obtain a greater understanding of the inherent properties of $D$. nodosus, a more detailed analysis of its rRNA genes was undertaken. This report describes the isolation and characterization, by Southern hybridization, sequence and primer extension analysis, of the three $r r n$ loci from $D$. nodosus strain A198, and provides an insight into the putative regulatory elements that control rRNA synthesis in D. nodosus.

\section{METHODS}

Bacterial strains, plasmids and bacteriophages. The $D$. nodosus strain used was the reference strain A198 (VCS1001). E. coli strains $\mathrm{DH} 5 \alpha\left[\mathrm{F}^{-}\right.$end $A 1$ bsd $17\left(\mathrm{r}_{\mathrm{m}}^{-} \mathrm{m}_{\mathrm{k}}^{+}\right)$thi-1 $\lambda^{-} \operatorname{rec} A 1$ gyr $A 96$ relA1 $\phi 80 \mathrm{~d} l a c Z \Delta \mathrm{M} 15]$ (Bethesda Research Laboratories) and $\mathrm{LE} 392\left[\mathrm{~F}^{-}\right.$supF58 supE44 bsd $\mathrm{R} 514\left(\mathrm{r}_{\mathrm{m}}^{-} \mathrm{m}_{\mathrm{k}}^{+}\right)$galK2 galT22 trpR 55 metB1 lac Y1] (Sambrook et al., 1989) were used for transformation with recombinant plasmids and for bacteriophage infection, respectively. Recombinant plasmids were derived from the vectors pUC18 (Yanisch-Perron et al., 1985), pBluescript II KS (Stratagene) and pWSK29 (Wang \& Kushner, 1991). Recombinant bacteriophages were derived from strain A198 genomic lambda libraries constructed in the vectors EMBL3 and LambdaGEM-12 (Katz et al., 1994).

Media and culture conditions. $D$. nodosus was cultured on hoof (Thomas, 1958), trypticase-arginine-serine (TAS) (Skerman, 1975), or Eugonagar (BBL) agar plates, and in either TAS broth or Eugonbroth (BBL). Cultures were incubated at $37^{\circ} \mathrm{C}$ for 3 $4 \mathrm{~d}$ (for plate cultures) or $48 \mathrm{~h}$ (for broth cultures), in an atmosphere containing $10 \% \mathrm{H}_{2}$ and $10 \% \mathrm{CO}_{2}$ in $\mathrm{N}_{2}$. E. coli DH5 $\alpha$ derivatives were cultured on 2 YT (Miller, 1972) solid and liquid media, while strain LE392 was cultured on solid and liquid L $+\mathrm{G}$ medium [LB medium (Sambrook et al., 1989) with the addition of $10 \mathrm{mM}$ Tris $/ \mathrm{HCl} \mathrm{pH} \mathrm{7.5,1} \mathrm{mM} \mathrm{MgCl}_{2}$ and $0.2 \%(\mathrm{w} / \mathrm{v})$ glucose] supplemented with $1 \%(\mathrm{w} / \mathrm{v})$ maltose. Ampicillin $\left(100 \mu \mathrm{g} \mathrm{ml}^{-1}\right)$ was added where required.

Preparation of nucleic acids and general molecular techniques. Total genomic DNA from $D$. nodosus was isolated from broth cultures as previously described (Anderson et al., 1984). Plasmid DNA was isolated by the methods of Birnboim \& Doly (1979) and Morelle (1989). DNA from recombinant bacteriophages was prepared from plate lysates as described by Sambrook et al. (1989). DNA fragments were excised from $0 \cdot 8-1 \cdot 2 \%(\mathrm{w} / \mathrm{v})$ agarose gels and purified using a Geneclean Kit (BIO 101), as recommended by the manufacturer. Oligonucleotides were chemically synthesized in an automatic DNA synthesizer (model 381A, Applied Biosystems). The cloning, analysis and manipulation of DNA, which included ligation reactions, transformation of plasmid DNA, restriction analysis, and agarose gel electrophoresis, was carried out essentially as described by Sambrook et al. (1989).
Total D. nodosus RNA was prepared from plate cultures as previously described (La Fontaine et al., 1993), or from broth cultures using TRISOLV (Biotecx Laboratories), as described by the manufacturer, with the inclusion of a 5 min incubation at $65^{\circ} \mathrm{C}$ after resuspending cells in the TRISOLV reagent. In addition, the isolated RNA was treated with RNase-free DNase I (RQ1, Promega; 1.0 unit) at $37^{\circ} \mathrm{C}$ for $30 \mathrm{~min}$, followed by a second round of extraction with TRISOLV. Individual rRNA molecules were isolated after electrophoresis and excision of individual bands from a $1.2 \%(\mathrm{w} / \mathrm{v})$ low-melting-temperature agarose (Seaplaque, FMC Bioproducts) gel. Purification involved melting the gel slice in an equal volume of distilled $\mathrm{H}_{2} \mathrm{O}$ $\left(\mathrm{dH}_{2} \mathrm{O}\right)$ at $70^{\circ} \mathrm{C}$ for $15 \mathrm{~min}$, followed by two extractions with phenol/chloroform/isoamyl alcohol (25:24:1, by vol.) and one with chloroform/isoamyl alcohol $(24: 1)$. RNA was precipitated from the aqueous phase as described by Baylis \& Bibb (1988a).

Labelling of nucleic acid probes. DNA fragments were labelled with $\left[\alpha^{-32} \mathrm{P}\right] \mathrm{dATP}\left[\sim 400 \mathrm{Ci} \mathrm{mmol}{ }^{-1}\left(\sim 14.8 \mathrm{TBq} \mathrm{mmol}^{-1}\right)\right.$; Amersham] using a GIGAprime DNA Labelling Kit (Bresatec), or with digoxigenin (DIG)-11-dUTP (Boehringer-Mannheim), using protocols recommended by the manufacturer. DNA probes were also generated by the incorporation of DIG-11dUTP during the polymerase chain reaction (PCR) as follows. Each $100 \mu \mathrm{l}$ PCR mixture contained approximately 200-500 ng template DNA, $1 \mu \mathrm{M}$ of each oligonucleotide primer, $180 \mu \mathrm{M}$ of each deoxynucleotide triphosphate (dNTP; Promega), $2 \mu \mathrm{l}$ of DIG DNA Labeling Mixture $(10 \times$ concentrated; BoehringerMannheim), 2.5 units of Taq DNA polymerase and $1 \times$ reaction buffer (Boehringer-Mannheim). The PCR mixture was placed in a thermal cycler (FTS-1 Thermal Sequencer, Corbett Research) and the temperature was cycled to $95^{\circ} \mathrm{C}$ for $1 \mathrm{~min}, 49^{\circ} \mathrm{C}$ for $1 \mathrm{~min}$ and $72^{\circ} \mathrm{C}$ for $1 \mathrm{~min}$, for $30-35$ cycles. The labelled PCR fragment was excised after electrophoresis through a $1.2 \%$ $(\mathrm{w} / \mathrm{v})$ low-melting-temperature agarose gel and boiled for $10 \mathrm{~min}$ in $\mathrm{dH}_{2} \mathrm{O}$ prior to use. Oligonucleotides were $5^{\prime}$ endlabelled with $\left[\gamma_{-}{ }^{32} \mathrm{P}\right]$ ATP $\left[>5000 \mathrm{Ci} \mathrm{mmol}{ }^{-1}(>185 \mathrm{TBq}\right.$ $\mathrm{mmol}^{-1}$ ); Amersham] and T4 polynucleotide kinase (Promega) as described by Keller \& Manak (1989). Unincorporated nucleotides were separated from labelled probes using NACS Prepac columns (Bethesda Research Laboratories). Labelled rRNA probes were prepared by hydrolysis as described by Arrand (1985) and then end-labelled with $\left[\gamma^{32} \mathrm{P}\right]$ ATP $(>$ $5000 \mathrm{Ci} \mathrm{mmol}^{-1}$ ) and $\mathrm{T} 4$ polynucleotide kinase.

Southern hybridization analysis. Digested DNA was fractionated by electrophoresis through $0.8 \%$ (w/v) agarose gels and transferred to nitrocellulose by the method of Southern (1975). Genomic DNA was also prepared and digested within agarose blocks as described by Smith \& Cantor (1987), and subjected to pulsed-field gel electrophoresis (PFGE) through a $0.8 \%$ (w/v) agarose gel using a CHEF-DR II apparatus (Bio$\mathrm{Rad}$ ). Electrophoresis was carried out at $150 \mathrm{~V}$ at $14^{\circ} \mathrm{C}$ using a ramped switch time of $0.5-1.0 \mathrm{~s}$ over $10 \mathrm{~h}$. The DNA was transferred to nitrocellulose as before, or to nylon membranes (Hybond- + , Amersham) under alkaline conditions using recommended protocols (Bio-Rad). Hybridization with $\left[\alpha-{ }^{32} \mathrm{P}\right] \mathrm{d}$ ATP-labelled DNA probes was carried out as already described (Katz et al., 1991). For DIG-11-dUTP-labelled DNA fragments, the manufacturer's protocols were used for the hybridization and washing of filters. In experiments which employed the DIG-11-dUTP-labelled PCR fragment as a probe, hybridization was carried out at $60^{\circ} \mathrm{C}$, and the highest stringency post-hybridization washes were carried out in $1 \times$ SSC, $0 \cdot 1 \%(\mathrm{w} / \mathrm{v}) \mathrm{SDS}$ at $60^{\circ} \mathrm{C}$. Hybridization with $\left[\gamma^{32} \mathrm{P}\right]$ A TPlabelled RNA probes was carried out at $50{ }^{\circ} \mathrm{C}$ in $50 \%(\mathrm{v} / \mathrm{v})$ deionized formamide, $2 \times$ Denhardt's solution (Sambrook et al., 1989), $5 \times$ SSC, $0 \cdot 2 \%(\mathrm{w} / \mathrm{v})$ SDS, $10 \mathrm{mM}$ EDTA and 
$0.5 \mathrm{mg}$ salmon sperm DNA $\mathrm{ml}^{-1}$. Washes were carried out in $2 \times$ SSC, $0.5 \%(\mathrm{w} / \mathrm{v})$ SDS, twice for $5 \mathrm{~min}$ at room temperature, and in $0.1 \times \mathrm{SSC}, 0.5 \%(\mathrm{w} / \mathrm{v}) \mathrm{SDS}$, twice for $10 \mathrm{~min}$ at $45{ }^{\circ} \mathrm{C}$. Conditions described elsewhere (La Fontaine et al., 1993) were employed for the hybridization of oligonucleotide probes to Southern blots.

Screening of genomic lambda libraries. Bacteriophage infection of the E. coli host LE392 was carried out as described by Sambrook et al. (1989). Recombinant bacteriophage DNA from plaques within the E. coli lawn were transferred to nitrocellulose filters (Schleicher and Schuell) as described by Sambrook et al. (1989), and hybridized with $\left[\alpha^{32} \mathrm{P}\right] \mathrm{dATP}$-labelled DNA probes under conditions described previously (Katz et al., 1991), or with DIG-11-dUTP-labelled probes as recommended by the manufacturer.

DNA sequence and primer extension analysis. Sequencing of double-stranded DNA templates was achieved using a T7 DNA polymerase sequencing kit (Pharmacia) and the recommended protocols. Primer extension experiments using approximately $50 \mu \mathrm{g}$ of total D. nodosus RNA extracted from broth cultures, and a commercially available Primer Extension System (Promega), were carried out according to the manufacturer's instructions. Primer extension products were analysed alongside DNA sequence ladders prepared using the appropriate templates and primers.

Computer analysis of the nucleotide and deduced amino acid sequences involved comparisons with the sequences in the nucleotide (GenBank and EMBL) and protein (SWISS-PROT, PIR and GenPept) sequence databases using the FASTA (Pearson \& Lipman, 1988) and BLAST (Gish \& States, 1993) programs. The analysis of rRNA sequences was facilitated using data and programs within the Ribosomal Database Project (RDP) (Maidak et al., 1994) and version 3.5c of PHYLIP (Phylogeny Inference Package) (Felsenstein, 1989).

\section{RESULTS AND DISCUSSION}

\section{Copy number and linkage of $D$. nodosus rRNA genes,} and isolation of the rrn loci

The sequence of the $D$. nodosus $16 \mathrm{~S}$ rRNA molecule (Dewhirst et al., 1990), and the isolation of the distal twothirds of a $D$. nodosus $16 \mathrm{~S}$ rRNA gene on the recombinant plasmid pJIR284 (La Fontaine \& Rood, 1990), was previously reported. However, it was determined subsequently that the portion of the pJIR284 insert that was located downstream of the 16S rRNA gene was devoid of rRNA-encoding sequences and did not constitute a contiguous region of the $D$. nodosus genome (data not shown). To isolate intact $r r n$ loci from D. nodosus, genomic lambda libraries derived from strain A198 were screened with a pJIR284-derived probe containing the cloned portion of the $16 \mathrm{~S} r R N A$ gene. The bacteriophage $\lambda R 33$ was one of six positive recombinants that were identified after screening approximately 1600 EMBL3-derived recombinant plaques, and was characterized in detail. By a combination of Southern hybridization with oligonucleotide and rRNA probes (data not shown), and sequence analysis, 16S, 23S and 5S rRNA genes were localized within the cloned insert (Fig. 1). The region of $\lambda$ R33 DNA carrying the three rRNA genes was designated $\operatorname{rrn} A$, in accordance with accepted nomenclature (Nomura et al., 1977).
Internal probes derived from each of the rRNA genes within $\lambda$ R33 (Fig. 1) were used to probe genomic DNA digests. With each probe, three hybridizing bands were evident in the NruI, HpaI and EcoRV digests (Fig. 2). In addition, the $H p a$ I hybridization profiles obtained with each probe were identical, as were the EcoRV profiles. These results showed that there were three copies of each of the rRNA genes within the strain A198 genome, and indicated a close linkage of the individual rRNA genes within each locus.

Further screening of approximately 1400 LambdaGEM12-derived recombinant plaques led to the isolation of the remaining two $r r n$ loci, $r r n B$ and $r r n C$, on $\lambda \mathrm{R} 38$ and $\lambda \mathrm{R} 104$, respectively. Restriction mapping and Southern hybridization analysis were used to localize the rRNA genes within these recombinants (Fig. 1). Although the regions containing the $16 \mathrm{~S}, 23 \mathrm{~S}$ and $5 \mathrm{~S}$ rRNA genes on $\lambda R 33, \lambda R 38$ and $\lambda R 104$ shared considerable restriction identity, the flanking regions had different restriction profiles, confirming that different $r r n$ loci had been isolated. Additional hybridization experiments confirmed that all of the rRNA genes had been isolated, that they were isolated on contiguous inserts, and that these inserts were derived from the strain A198 genome (data not shown).

\section{Nucleotide sequence analysis of the $r$ rn leader regions - identification of putative regulatory elements, the transcriptional start site and the $5^{\prime}$ mature 165 rRNA terminus}

To identify the regulatory elements involved in the synthesis and processing of the rRNA molecules in $D$. nodosus, the regions flanking the rRNA genes from each of $\lambda \mathrm{R} 33, \lambda \mathrm{R} 38$ and $\lambda \mathrm{R} 104$ were subcloned and their nucleotide sequences were determined. For $r r n$, the sequence of $485 \mathrm{bp}$ upstream of the $16 \mathrm{~S}$ rRNA gene was determined on both strands, and that of an additional 124 bases was obtained for one strand only. For $r r n B$ and $r r n C$, the sequence of 465 and 540 nucleotides, respectively, was determined on one strand upstream of the $16 \mathrm{~S}$ rRNA gene. The sequences of $r r n A, r r n B$ and $r r n C$ were identical for 247 nucleotides upstream of the sequence encoding the mature $16 \mathrm{~S}$ rRNA molecule. Thereafter, the sequence of $r r n A$ diverged from those of $r r n B$ and $r r n C$, which remained identical for an additional 60 nucleotides (Fig. 3).

Within the $r r n$ leader regions, several putative regulatory elements were identified. Two potential promoter sequences (P1 and P2), which had -10 and -35 elements with similarity to the E. coli $\sigma^{70}$-containing RNA polymerase (RNAP) consensus binding sites (Rosenberg \& Court, 1979), were identified (Fig. 3). However, based on the suboptimal 14 bp spacing between the P2 -10 and -35 elements, and their location relative to the start of the mature $16 \mathrm{~S} r \mathrm{RNA}$ sequence, it was unlikely that $\mathrm{P} 2$ would be functional. In addition, primer extension analysis with total $D$. nodosus RNA and oligonucleotide \#115 (Fig. 3) failed to detect any transcripts initiated from P2. However, primer extension analysis with oligo- 

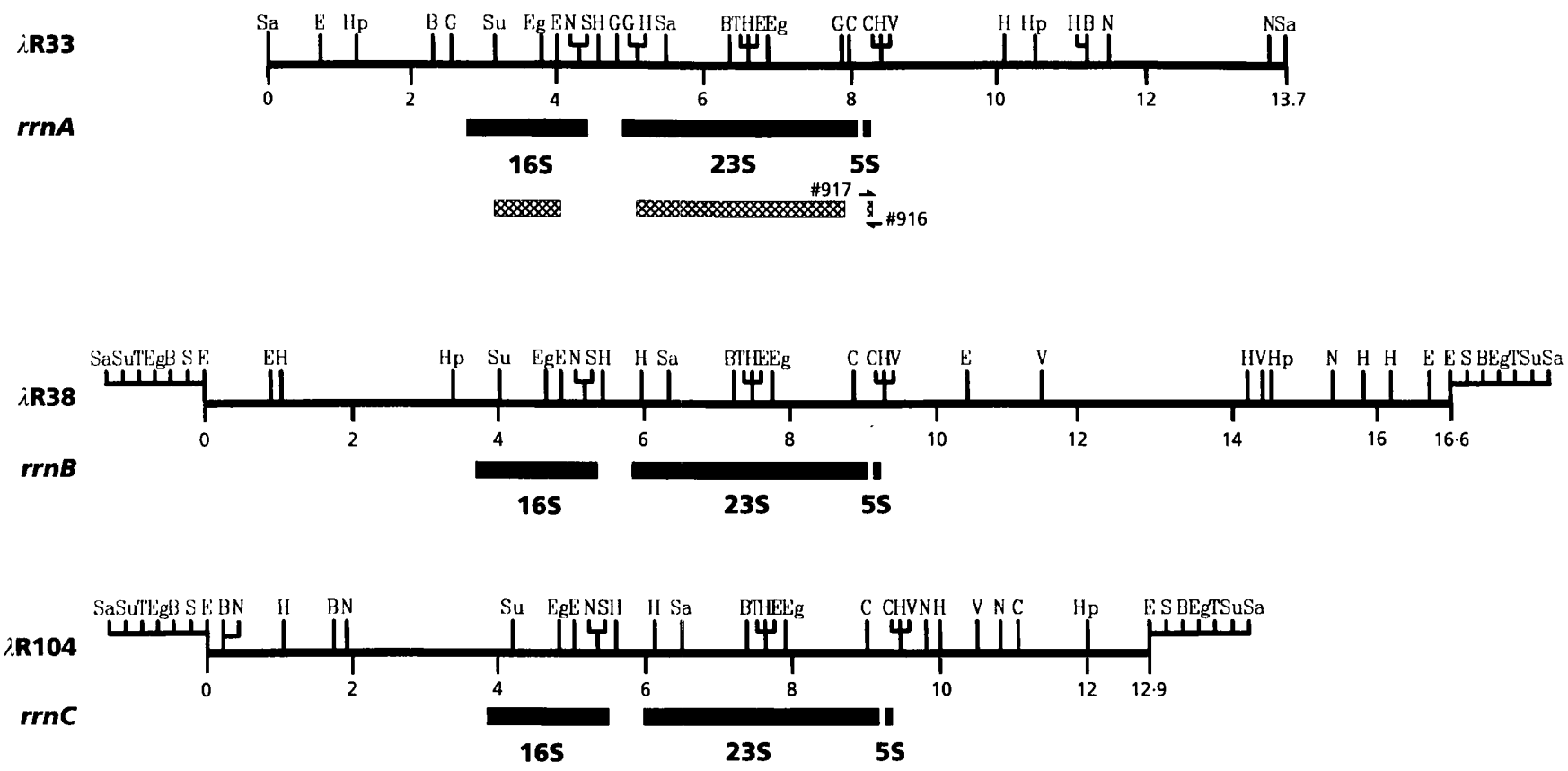

\begin{abstract}
Fig. 1. Restriction maps of $\lambda$ clones carrying $r r n A, r r n B$ and $r r n C$. Solid bars indicate the approximate location of the rRNA genes. Map scale is in $\mathrm{kb}$. The cross-hatched bars indicate the probe regions that were used for Southern hybridization experiments. The $16 \mathrm{~S}$ and $23 \mathrm{~S}$ rRNA gene probes comprised a $0.6 \mathrm{~kb}$ Stul-EcoRI fragment from a plasmid subclone of $\lambda R 33$, and a $2.6 \mathrm{~kb} \mathrm{Bg} / \mathrm{ll}$ fragment isolated from $\lambda R 33$, respectively. The $5 \mathrm{~S}$ rRNA gene probe was a 107 bp PCR fragment derived from $\lambda$ R33 DNA using the oligonucleotides \#916 (5' AACCTGATACTGTCC $3^{\prime}$ ) and \#917 (5' ATAGAGCTGTGGTAC $3^{\prime}$ ), which were complementary to the $3^{\prime}$ and $5^{\prime}$ ends of the $D$. nodosus $5 S$ rRNA gene, respectively. The vector-derived Sall sites at either end of the EMBL3-derived clone $\lambda R 33$ are shown. Only the polylinker sites remaining in the LambdaGEM-12 clones ( $\lambda$ R38 and $\lambda R 104)$, and which were used for mapping, are shown. Restriction enzyme abbreviations: B, BamHI; C, Scal; E, EcoRI; Eg, Eagl; G, Bg/ll; H, HindIII; Hp, Hpal; N, Nrul; P, Pvull; S, Smal; Sa, Sall; T, Sstl; Su, Stul; V, EcoRV.
\end{abstract}

(a)

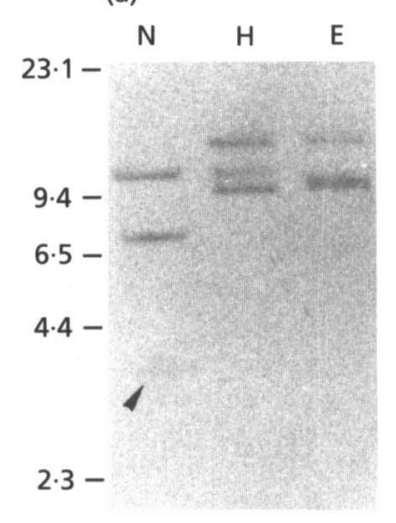

(b)

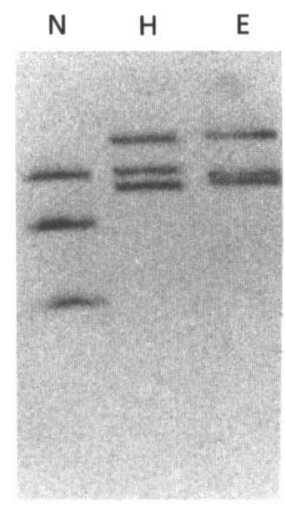

(c)

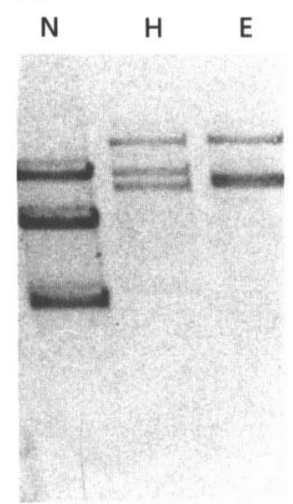

Fig. 2. Copy number and linkage of $D$. nodosus rRNA genes. $\mathrm{Nrul}(\mathrm{N}), \mathrm{Hpal}(\mathrm{H})$ and EcoRV (E) digests of $D$. nodosus strain A198 genomic DNA were subjected to PFGE as described in Methods. The digested DNA was transfered to nitrocellulose filters, and probed with DIG-labelled DNA probes specific for the 16S (a), 235 (b) and $5 S$ (c) rRNA molecules. The arrow indicates the position of a faint band. The sizes and mobilities of the $\lambda \mathrm{Cl} / 857$ HindIII size standards are indicated in $\mathrm{kb}$. nucleotide \#1154 (Fig. 3) confirmed that $r r n$ transcription initiated from $\mathrm{P} 1$, with the $\mathrm{T}$ residue located eight bases downstream of the -10 hexamer (Fig. 4a). The existence of what appeared to be only a single rrn promoter in $D$. nodosus was in contrast to the presence of multiple rrn promoters in E. coli (Wagner, 1994). Prior to this study, only one other $D$. nodosus promoter, that of the fimbrial operon, had been mapped (Hobbs et al., 1991). The fim promoter elements resembled those which are bound by $\sigma^{54}$-containing RNAP and which are characteristically regulated by an activator protein (Kustu et al., 1989). Therefore, the $r r n$ promoter is the first $D$. nodosus promoter to be mapped which shows similarity to elements that are recognized by the major sigma factor, $\sigma^{70}$ (Rosenberg \& Court, 1979).

The GC-rich region (GCGCACC) located immediately 3' of the -10 hexamer of P1 (Fig. 3), was similar to the discriminator motif (GCGC) that is characteristic of stringently controlled promoters, which include the $r r n$ 


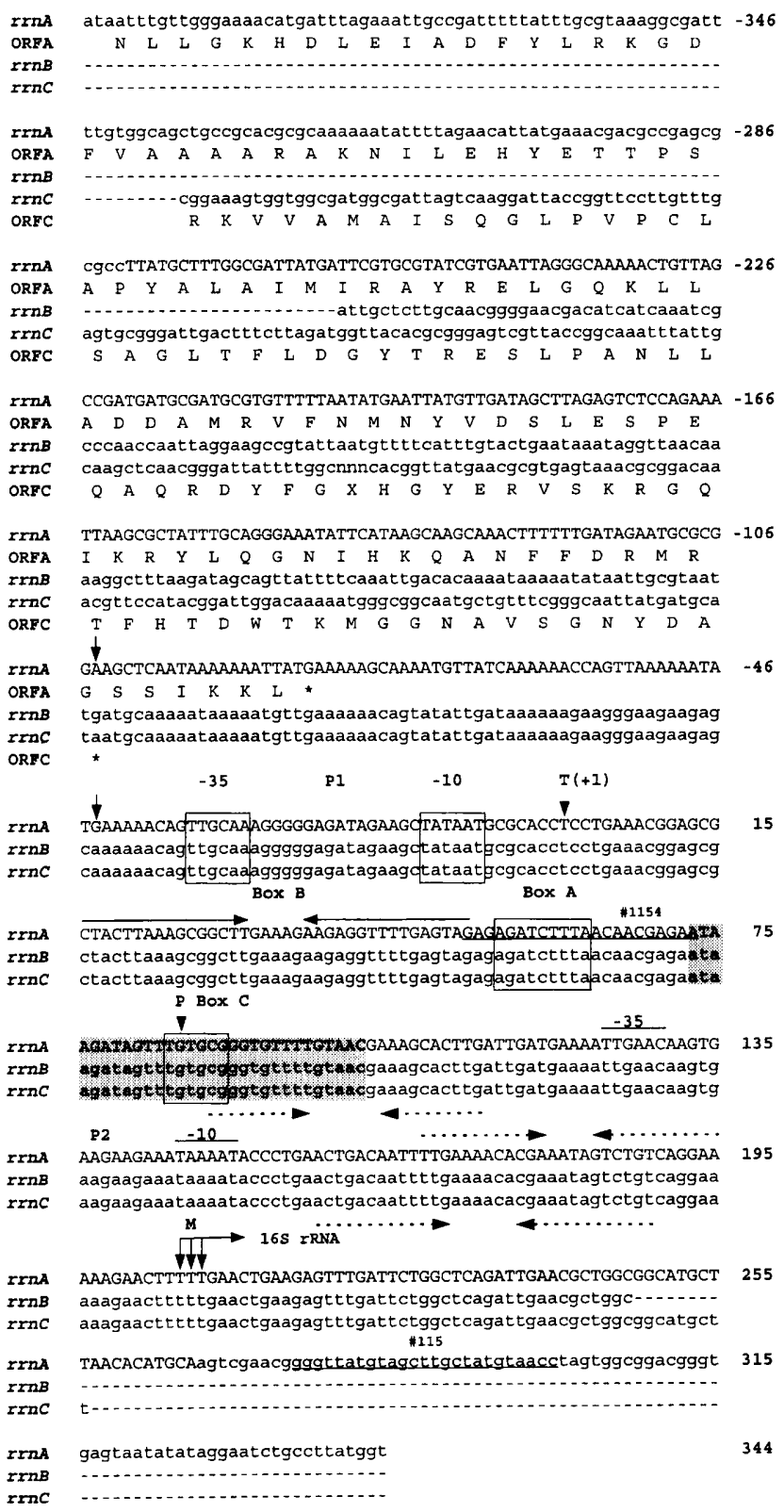

Fig. 3. Nucleotide and deduced amino acid sequences of the regions upstream of $r r n A, r r n B$ and $r r n C$. Amino acid sequences are shown below the corresponding nucleotide sequences. Stop codons are indicated by an asterisk. Dashes represent unsequenced regions, uppercase letters indicate doublestranded sequence and lowercase letters indicate singlestranded sequence. Nucleotides that could not be determined are denoted by ' $n$ ', and amino acids that could not be deduced are indicated by ' $X$ '. Vertical arrows above the $\operatorname{rrnA}$ sequence indicate the point of sequence divergence between $\operatorname{rrnA}$ and $r r n B / r r n C$, and between $r r n B$ and $r r n C$. The numbers correspond to the $r$ rnA sequence, with +1 representing the start point of transcription ( $T$ ), which is indicated by a filled arrow. Filled arrows also indicate start points of premature $(P)$ and mature (M) 16S rRNA transcripts. The sequences of the oligonucleotides that were used for primer extension experiments are underlined. The $-10 /-35$ hexamers of the P1 promoter are boxed, as are putative box $A$ and box $C$ sequences. The region of box B dyad symmetry is indicated by arrows above the sequence. Other regions of dyad symmetry that may participate in the formation of secondary structures are indicated by broken arrows below the sequence. Nucleotides that are likely promoters (Wagner, 1994). Sequences upstream of the - 35 hexamer of strong promoters, such as those of stable RNA genes, characteristically have a high $\mathrm{A}+\mathrm{T}$ content, which is associated with DNA curvature in these regions (Pérez-Martín et al., 1994). Regions upstream of the E. coli $r r n B$ P1 promoter are AT-rich and are involved in the activation of rRNA transcription, through the interaction of the UP element (an AT-rich region from -40 to -60 ) with the $\alpha$ subunit of RNAP, and through the binding of FIS (factor for inversion stimulation) at regions upstream of the UP element (Pérez-Martín et al., 1994). An additional protein, H-NS, was reported to be involved in repression of rRNA transcription, and like FIS, requires curved DNA (Wagner, 1994). In D. nodosus, the region upstream of the P1 promoter was low in $G+C$, but numerous poly (A) stretches were present (Fig. 3) rather than the usual intermingling of poly (A) and poly $(\mathrm{T})$ tracts observed upstream of the E. coli rRNA operons (JinksRobertson \& Nomura, 1987). Several of these poly(A) tracts, particularly within $\operatorname{rrn} A$, were appropriately phased within the helical repeat, and may contribute to an altered DNA conformation in this region. However, upstream of the $E$. coli $r r n B$ core promoter, despite multiple A/T tracts, the major DNA bend was located upstream of the elements which contribute to rrn transcriptional activation (Gaal et al., 1994). Within the D. nodosus upstream regions, sites reminiscent of consensus FIS binding sites (Finkel \& Johnson, 1992) were also identified. By analogy with the equivalent region of the $E$. coli $\mathrm{rRNA}$ operons, sequences within the $r r n$ leader region may contribute to the activation and repression of rRNA transcription in $D$. nodosus.

Premature termination of $r r n$ transcription is prevented by the existence of antitermination mechanisms similar to those of lambdoid phages (Berg et al., 1989). Regions equivalent to the nut loci (boxes $\mathrm{A}, \mathrm{B}$ and $\mathrm{C}$ ) that are involved in the bacteriophage lambda antitermination system (Friedman \& Gottesman, 1983), have been identified within the rrn leader and spacer regions of many bacteria (Berg et al., 1989), and were also present downstream of the D. nodosus rrn P1 promoter (Fig. 3). The putative $D$. nodosus box A sequence had seven of the nine consensus nucleotides defined for box $\mathrm{A}$ sequences [(C/T)GCTCTT(T/-)A] (Friedman \& Gottesman, 1983). A putative box $\mathrm{B}$ element, which is not a conserved sequence but a region of hyphenated dyad symmetry, was identified $5^{\prime}$ to the box A element (Fig. 3), a location that is common to the $r r n$ antitermination system (Berg et al., 1989). The $D$. nodosus box B element had the potential to form two possible hairpin loops with either a five- or a 15 nucleotide GA-rich loop that is characteristic of both phage (Friedman \& Gottesman, 1983) and rrn box B regions (Berg et al., 1989). Twenty-one nucleotides

to be involved in the formation of a processing stem with a region downstream of the 165 rRNA sequence are in bold type and shaded. The potential P2 promoter sequences are also indicated. The GenBank accession numbers for the $r r n A$, $r r n B$ and $r$ rnC leader sequences are U26680, U26681, and U26682, respectively. 
(a)

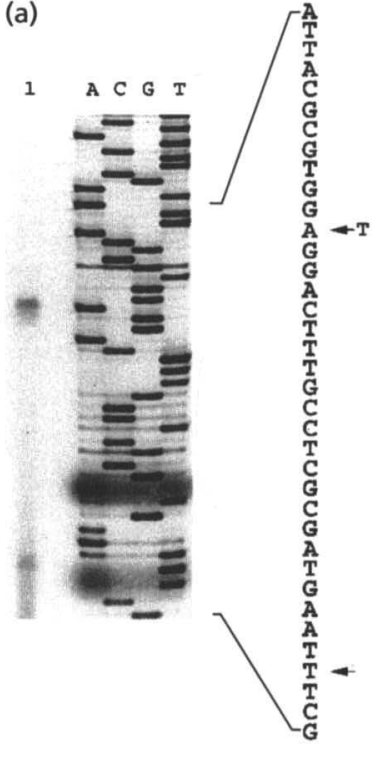

(b)

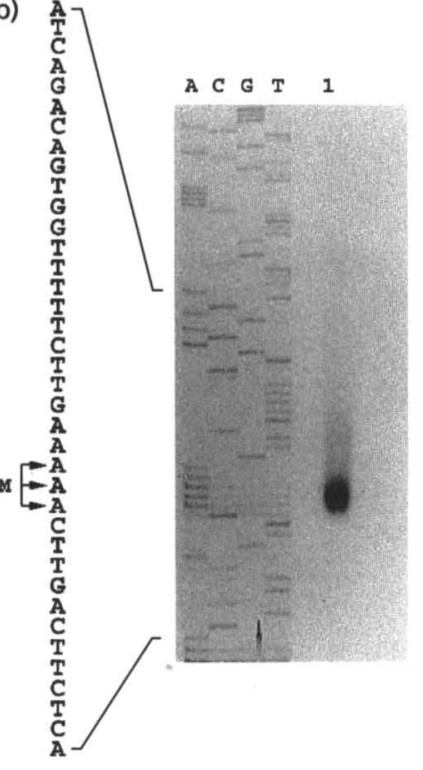

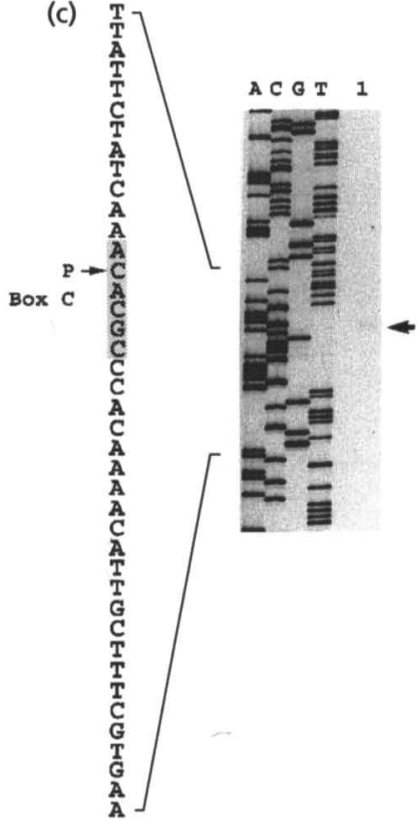

Fig. 4. Primer extension analysis of strain A198 rRNA transcripts. (a) Primer extension analysis of the $r r n$ transcription start point. \#1154-derived primer extension products (lane 1) were subjected to polyacrylamide gel electrophoresis, alongside the sequencing ladder (lanes A, C, G and T) obtained using oligonucleotide \#1154 and a $\lambda$ R33-derived plasmid containing the $r$ rn leader region. The DNA sequence of the region surrounding the starting nucleotide is shown. Note that this sequence represents that of the antisense strand. The nucleotide representing the transcription start point $(T)$ is indicated. An additional product consistently observed in this primer extension reaction is also indicated. (b, c) Primer extension analysis of mature and premature rRNA start points using oligonucleotide \#115. The DNA sequence of the regions surrounding the starting nucleotides, again representing that of the antisense strand, is shown. The start points of (b) the mature (M) $16 \mathrm{~S}$ rRNA and $(c)$ a premature $(P)$ transcript, are indicated by arrows as is the primer extension product in (c). The sequence of the putative box $C$ is shaded.

downstream of the box A sequence, a sequence was identified that resembled the phage and E. coli rrn box C sequence, which consists of an alternating GT-rich pattern $[\mathrm{GG}(\mathrm{T} / \mathrm{C}) \mathrm{GT}(\mathrm{G} / \mathrm{A})(\mathrm{T} / \mathrm{C}) \mathrm{G}]$ (Friedman \& Gottesman, 1983) (Fig. 3).

Primer extension analysis with oligonucleotide \#115 resulted in a consistent, albeit somewhat heterogeneous, product which spanned several nucleotides (Fig. 4b) and represented the $5^{\prime}$ end of the mature $16 \mathrm{~S}$ rRNA molecule. The sequence of the $D$. nodosus $16 \mathrm{~S}$ rRNA was previously reported from nucleotide position 2 , which was shown to be an A residue (Dewhirst $e t$ al., 1990). Primer extension analysis indicated that the sequence immediately adjacent to this nucleotide was... TTTTTG (Fig. 3) and that the $5^{\prime}$ nucleotide of the mature $16 \mathrm{~S}$ rRNA (M) could be localized to one of the three $T$ residues immediately preceding the $G$ (Fig. 4b). A longer exposure of the autoradiograph revealed the presence of a primer extension product of 216 nucleotides (Fig. 4c), which was consistently observed. The nucleotide corresponding to this band may represent the $5^{\prime}$ end of a premature $(\mathrm{P})$ form of the $16 \mathrm{~S}$ rRNA. This nucleotide occurred within a sequence of 30 nucleotides (Fig. 3), an inverted form of which was present downstream of the 16S rRNA gene (Fig. 5a).

\section{Identification of tRNA genes within the 16S-23S rRNA spacer}

The nucleotide sequence of the $16 \mathrm{~S}-23 \mathrm{~S}$ rRNA intergenic spacer region, the $5^{\prime}$ and $3^{\prime}$ termini of the $23 \mathrm{~S}$ rRNA gene, the 23S-5S rRNA intergenic spacer, the 5S rRNA gene and 300 bp downstream, was determined for both strands of $r r n A$ (Fig. 5), but for only one strand of $r r B$ and $r r n C$ since their sequences were identical. The $3^{\prime}$ nucleotides of the $D$. nodosus $16 \mathrm{~S}$ rRNA molecule were determined previously (Dewhirst et al., 1990), while the 5' and 3' termini of the $23 \mathrm{~S}$ rRNA gene were assigned by comparison with published sequences within the Ribosomal Database Project (Maidak et al., 1994). The 16S-23S spacer region contained putative $\mathrm{tRNA} \mathrm{Al}^{\text {Ile }}$ and $\mathrm{tRNA} \mathrm{Ala}^{\text {Ala }}$ genes (Fig. 5a) which had 62-89\% and 52-98\% sequence identity, respectively, with equivalent genes from other organisms. These sequences were able to fold into the compact cloverleaf structure characteristic of tRNA molecules, and contained anticodons specifying Ile and Ala within the anticodon arms of the respective molecules. The presence of tRNA genes within the 16S-23S spacer regions is another common, but not universal, feature of rRNA operons (Krawiec \& Riley, 1990), and in many cases there appears to be a bias towards the presence of 


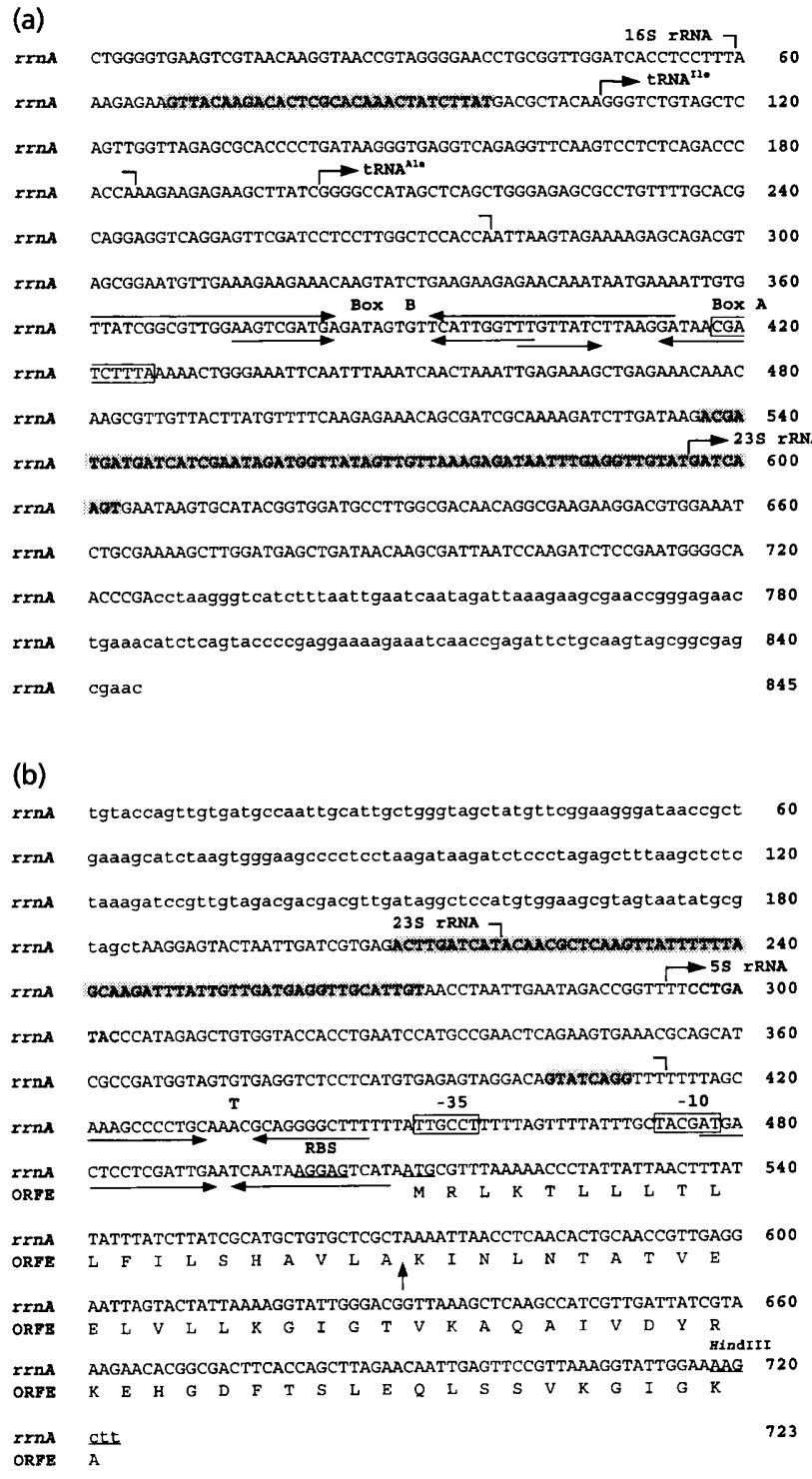

Fig. 5. Nucleotide sequence of the $r$ rn spacer and distal regions. Only the sequence obtained from the rrnA operon is shown, since the $r r n B$ and $r r n C$ sequences were identical. Uppercase letters represent double-stranded sequence and lowercase letters represent single-stranded sequence. The $3^{\prime}$ end of the $16 \mathrm{~S}$ rRNA gene and the proposed $3^{\prime}$ ends of the tRNA and 235 and $5 S$ rRNA genes are indicated by bent lines. The putative $5^{\prime}$ ends of the tRNA genes and the 235 and $5 S$ rRNA genes are indicated by bent arrows. Nucleotides potentially involved in the formation of $16 \mathrm{~S}, 23 \mathrm{~S}$ and $5 \mathrm{~S}$ rRNA processing stems are in bold type and shaded. (a) Nucleotide sequence of the 16S-235 rRNA spacer region (GenBank accession number U26683). A putative box $A$ sequence is boxed, and regions of dyad symmetry, which may function as box B, are indicated by arrows. (b) Sequence of the 3' region of the rrn loci (GenBank accession number U26684). The deduced amino acid sequence of ORFE, which was adjacent to all three rrn loci, is shown below the nucleotide sequence. Regions of dyad symmetry, one representing the putative terminator $(T)$, and the other immediately preceding ORFE, are indicated by arrows. Putative $-10 /-35$ hexamers are boxed, and the potential ribosomebinding site (RBS) and ATG start codon for ORFE are underlined. The vertical arrow shows the predicted point of cleavage of the putative ORFE signal peptide from the mature protein. tandemly arranged $\mathrm{tRNA}^{\mathrm{Ile}}$ and $\mathrm{tRNA}^{\mathrm{Ala}}$ genes (Loughney et al., 1982; Jinks-Robertson \& Nomura, 1987; Nakagawa et al., 1992; Gill et al., 1994; Minnick et al., 1994). Although the significance of the association of these particular tRNA genes with $r r n$ spacers remains unclear, perhaps they represent an ancestral feature of rRNA operons and a lack of selective pressure over time has resulted in non-uniformity with respect to the presence of $\mathrm{tRNA}^{\mathrm{Ile}}$ and $\mathrm{tRNA}{ }^{\mathrm{Ala}}$ genes in $\mathrm{rNA}$ operons within and between organisms. Between the $t R \mathrm{NA}^{\mathrm{Ala}}$ and the $23 \mathrm{~S}$ rRNA genes, additional putative box $\mathrm{A}$ and box $B$ elements were identified, which also are common among bacterial rrn spacer regions (Berg et al., 1989).

The 23S-5S rRNA spacer region (Fig. 5b) did not show any significant similarity to sequences within the nucleotide databases. The mature termini of the $5 \mathrm{~S}$ rRNA gene were assigned by comparison with other bacterial $5 \mathrm{~S}$ rRNA gene sequences, and a putative factor-independent transcription termination signal (T) $[\Delta G=-29 \mathrm{kcal}$ $\mathrm{mol}^{-1}\left(-121 \mathrm{~kJ} \mathrm{mmol}^{-1}\right)$, calculated by the method of Tinoco et al. (1973)] was identified seven nucleotides downstream from the $3^{\prime}$ terminus (Fig. 5b).

\section{Sequence and structural analysis of the 5S rRNA gene}

The $D$. nodosus $5 \mathrm{~S}$ rRNA gene was approximately $120 \mathrm{bp}$ in length. Using a secondary structure model for $5 \mathrm{~S}$ rRNA sequences that was derived from comparative sequence analysis, biochemical and chemical studies (Specht et al., 1990), a secondary structure for the $D$. nodosus $5 \mathrm{~S}$ rRNA was deduced from its gene sequence (data not shown). This structure, comprising five helical segments, A to E, connected by loops a to e, conformed to the minimal model of secondary structure proposed for an ur-5S rRNA, and included the variation proposed for the minimal model of eubacterial 5S rRNA (Specht et al., 1990). In addition, the $D$. nodosus-derived structure contained features in common with those of other Proteobacteria, which included an A : C base pair at position 11:109 and a three-base loop e, the latter common to gamma group structures.

Comparison of the $D$. nodosus $5 \mathrm{~S}$ rRNA sequence with that from organisms of the beta and gamma groups of the Proteobacteria showed that the $D$. nodosus sequence shared 61-67\% and 78-82\% sequence identity with members of these groups, respectively. As expected from these results, $D$. nodosus clustered with other gamma group bacteria within 5S rRNA-based phylogenetic trees (data not shown). Therefore, comparative analysis of the deduced primary and secondary structures of the $5 \mathrm{~S}$ rRNA from $D$. nodosus has provided independent confirmation of its phylogenetic position within the gamma division of the Proteobacteria, which was initially determined by $16 \mathrm{~S}$ rRNA-based phylogenetic analyses (Dewhirst et al., 1990).

\section{Signals for the processing of rRNA precursors}

Within the $D$. nodosus rrn loci, the sequences encoding the mature $16 \mathrm{~S}$ and $23 \mathrm{~S}$ rRNA molecules were bordered by sequences with the potential to form double-stranded 


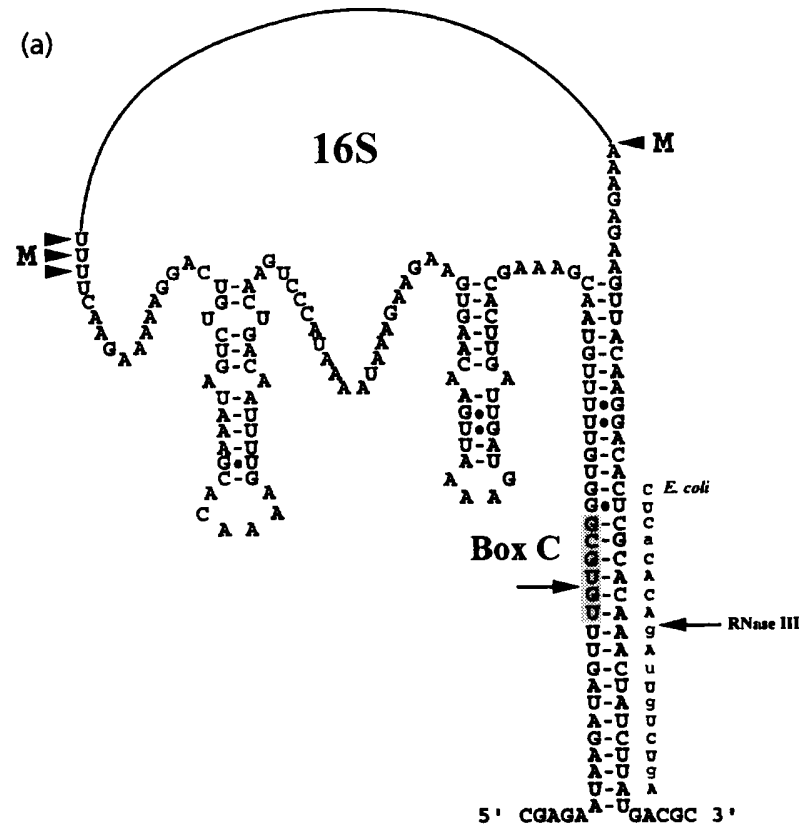

(b)

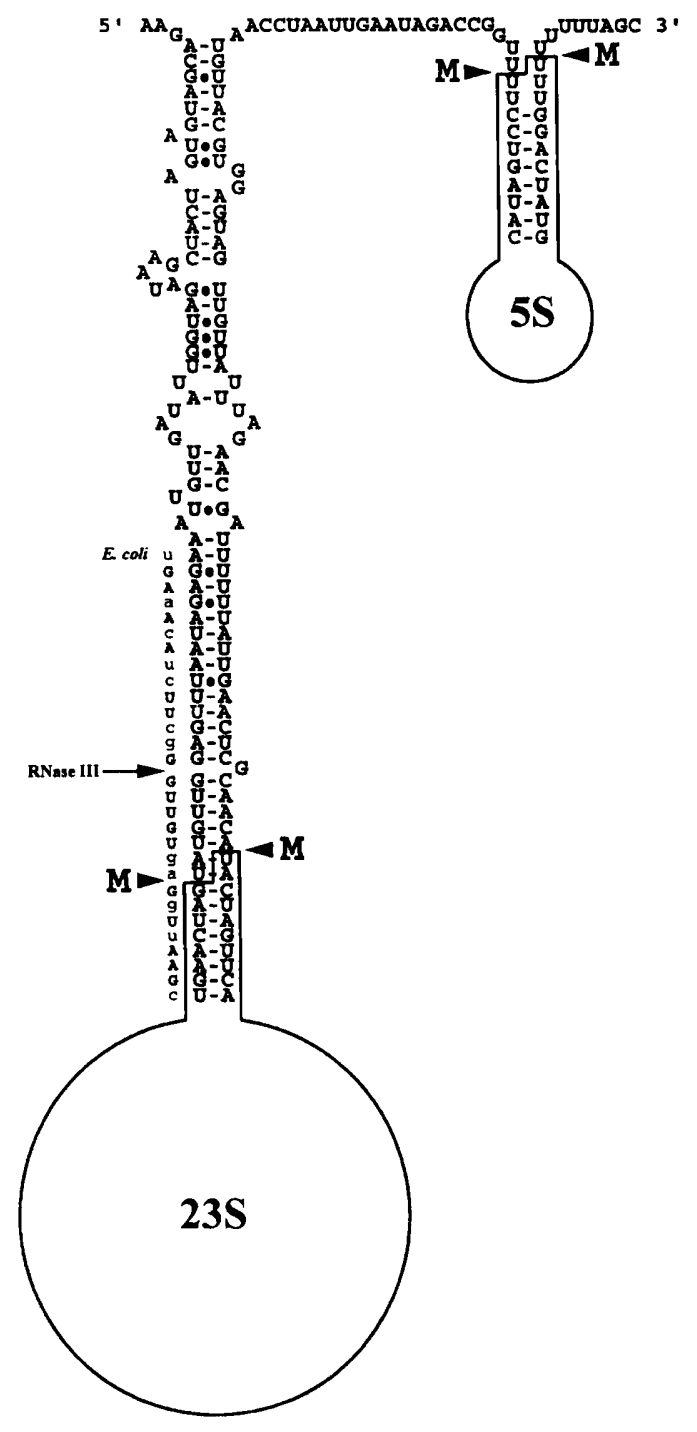

stem structures (Fig. 6). These structures are yet another conserved feature of rRNA operons, and contain the primary processing sites for RNase III in E. coli, or its equivalent in other organisms (Srivastava \& Schlessinger, 1990). The $9 S$ precursor containing the $5 \mathrm{~S}$ rRNA sequence is cleaved by RNase E, and the resultant molecule, as well as the pre-16S and pre-23S rRNAs, are acted upon by additional endo- and exoribonucleases to produce the mature termini (Srivastava \& Schlessinger, 1990). In D. nodosus 30 nucleotides flanking the $16 \mathrm{~S}$ rRNA sequence (Figs 3 and 5a) had the potential to participate in stem formation (Fig. 6a), in contrast to the approximately 45 stem-forming nucleotides flanking the E. coli $16 \mathrm{~S}$ rRNA sequence (Srivastava \& Schlessinger, 1989). These bases in both E. coli (Srivastava \& Schlessinger, 1989) and $D$. nodosus (Figs 3 and 6 ) included the box $\mathrm{C}$ sequence. Cleavage by E. coli RNase III occurs within this sequence (Srivastava \& Schlessinger, 1989), and in D. nodosus, a primer extension product obtained using oligonucleotide \#115 (Fig. 4c) was consistent with cleavage within the putative box $\mathrm{C}$ sequence.

As in E. coli (Srivastava \& Schlessinger, 1990), the putative $23 \mathrm{~S}$ rRNA processing stem included nucleotides at the $5^{\prime}$ and $3^{\prime}$ mature termini (Figs 5 and $6 \mathrm{~b}$ ). Terminal nucleotides of the $5 \mathrm{~S}$ rRNA sequence also had the potential to participate in the formation of a short doublestranded stem (Fig. 6b). The point(s) of cleavage that would lead to the generation of premature and mature $23 \mathrm{~S}$ and $5 \mathrm{~S}$ rRNA molecules were not determined. Although the specificity of $E$. coli RNase III is likely to involve secondary and tertiary structural features of the RNA (Srivastava \& Schlessinger, 1990), and despite the sequence differences in the stem structures associated with $D$. nodosus rRNA molecules compared with those of $E$. coli, there were regions of limited sequence similarity which, in E. coli, corresponded to regions surrounding the sites of RNase III cleavage (Fig. 6).

\section{Analysis of putative ORFs flanking the $r r n$ loci}

The nucleotide and deduced amino acid sequences of the regions located upstream and downstream of the $r r n$ loci were compared with the sequences in the nucleotide and protein sequence databases. The C-terminal ends of

Fig. 6. Potential processing stems for $D$. nodosus rRNA molecules. Lines denote standard base pairs and filled circles denote $G: U$ base pairs. Filled arrows indicate the mature termini $(\mathrm{M})$ of the rRNA molecules as identified for the 165 rRNA, and as proposed for the 235 and $5 S$ rRNAs. (a) Processing stem for $16 \mathrm{~S}$ rRNA and potential secondary structures that may form from sequences within the $r r n$ leader region. Box $C$ within the stem is shaded and the point of cleavage within box $C$ is indicated by an arrow. The $E$. coli sequence surrounding the RNase III cleavage site within the stem-forming sequence that flanks the 16S rRNA 3' terminus (Srivastava \& Schlessinger, 1989 ), is also shown. $E$. coli nucleotides that are identical with those in the $D$. nodosus sequence are in uppercase bold type. (b) Putative processing stem for $23 S$ and $5 S$ rRNAs. The E. coli sequence surrounding the RNase III cleavage site within the stem-forming sequence that flanks the 23S rRNA $5^{\prime}$ terminus is also shown. E. coli nucleotides that are identical with those in the $D$. nodosus sequence are in uppercase bold type. 
potential ORFs, designated ORFA and ORFC, were identified upstream of $r n A$ and $r r n C$ (Fig. 3), respectively, and identical copies of a putative ORF, ORFE, were located downstream of all three $r r n$ loci (Fig. 5b).

ORFA had $37 \cdot 0 \%$ amino acid sequence identity, over an 81 amino acid region, with a hypothetical protein, ORFY, of unknown function from Pseudomonas aeruginosa (Hobbs et al., 1993). The latter ORF is located between the pils/pilR locus and the $c l p B$ gene in $P$. aeruginosa. ORFC had $48-57 \%$ amino acid sequence identity with the Cterminus of 6-phosphogluconate dehydrogenases (6PGD) from both bacteria and eukaryotes, and contained one of the signature sequences, NLXQAQR, which may be used to identify 6-PGD sequences (Reizer $e$ t al., 1991). ORFE encoded a putative polypeptide of more than 71 amino acids, which had a hydrophobic $\mathrm{N}$-terminal domain that could function as a signal peptide. Over a 49 amino acid region, ORFE had $49 \%$ and $40.8 \%$ amino acid sequence identity with DNA binding proteins from Bacillus subtilis (ORF1 of the comE operon; Hahn et al., 1993), and from Homo sapiens (OBP-1 and OBP-2; Zhang \& Nonoyama, 1994), respectively.

ORFs have been identified upstream of rRNA operons from other bacteria, including the Streptomyces coelicolor $r r n D$ operon (Baylis \& Bibb, 1988b), an rRNA operon from Thiobacillus ferrooxidans (Takamiya et al., 1990), and the E. coli rrnB operon (Brosius et al., 1981), with the $c l p B$ gene located upstream of the E. coli rrnG operon (Squires et al., 1991). There does not appear to be any functional significance as to which genes or ORFs reside in close proximity to rRNA operons but, as observed for $D$. nodosus ORFA and ORFC, neither the E. coli rrnB, S. coelicolor $r r n D$, nor the $T$. ferrooxidans $r R N A$ operons were followed by any obvious factor-independent transcription termination signals. In $D$. nodosus, termination of transcription of ORFA and ORFC may be factor-independent, or transcription may continue uninterrupted into the rRNA operons, as occurs with the ORF upstream of $\mathrm{rrnB}$ from E. coli (Boros et al., 1983).

\section{Conclusions}

Analysis of the $D$. nodosus $\mathrm{rRNA}$ genes revealed that there were three copies of each $r$ rn locus within the D. nodosus strain A198 genome, each comprising closely linked genes encoding the 16S, 23S and 5S rRNAs, with tRNA ${ }^{\text {Ile }}$ and tRNA ${ }^{\text {Ala }}$ genes located between the $16 \mathrm{~S}$ and $23 \mathrm{~S}$ rRNA genes. In D. nodosus, transcription of each rrn locus appeared to originate from a single E. coli-like promoter that was mapped upstream of the $16 \mathrm{~S}$ rRNA gene. This gene order is similar to that determined for many other bacteria, although it is not universal (Krawiec \& Riley, 1990; Srivastava \& Schlessinger, 1990; Menke et al., 1991).

Based on the restriction identity between the rRNA coding regions, and the sequence identity between the sequenced regions of all three $r r n$ loci, it is concluded that the three D. nodosus rRNA operons have arisen through precise duplications, and that the multiple copies of
ORFE arose as a result of its duplication along with the rRNA operons. Although restriction site differences between the three loci were observed downstream of the sequenced region of ORFE (Fig. 1), further sequence analysis will be required to determine the full extent of the identity, and the point of divergence, between the three loci. The apparent lack of heterogeneity between $\mathrm{rrn}$ loci may reflect the absence of sequence-associated drift, or it may indicate that the sequences within and surrounding the rRNA and tRNA genes are functionally important.

Although there is no correlation between rRNA gene copy number and genome size, an observed trend is that slow-growing organisms have fewer rRNA gene copies than more rapidly growing bacteria (Krawiec \& Riley, 1990). Although rrn gene copy number must influence growth rate to a large extent, other factors such as genome size and complexity, which in turn determine an organism's physiological and metabolic capabilities, and perhaps $r r n$ promoter strength and efficiency, must also be important. $D$. nodosus is a slow-growing bacterium with complex growth requirements, and it is not known if all three of its rRNA operons are required to support the maximum growth capacity of this organism. In addition, compared with fast-growing bacteria such as $E$. coli (Wagner, 1994) and Clostridium perfringens (Garnier et al., 1991) which have multiple $r r n$ promoters that are, or appear to be, differentially regulated, the probable presence of a single functional $r r n$ promoter in D. nodosus may imply a less complex, albeit less efficient, system for the synthesis of rRNA in this bacterium, and may be a factor contributing to its slow growth rate.

\section{ACKNOWLEDGEMENTS}

We thank Stephen Billington and Volker Haring for helpful discussions and assistance with computing, Joan Sloan, Pauline Howarth and Tracey Warner for their most valuable technical assistance, and Eric Moses for kindly providing the $D$. nodosus strain A198 genomic lambda libraries. We acknowledge the strong support of the Australian Wool Research and Development Corporation. S. L. was the recipient of an Australian Wool Corporation Postgraduate Research Scholarship.

\section{REFERENCES}

Anderson, B. J., Bills, M. M., Egerton, J. R. \& Mattick, J. S. (1984). Cloning and expression in E. coli of the gene encoding the structural subunit of Bacteroides nodosus fimbriae. J Bacteriol 160, 748-754.

Arrand, J. E. (1985). Preparation of nucleic acid probes. In Nucleic Acid Hybridization. A Practical Approach, pp. 17-45. Edited by B. D. Hames \& S. J. Higgins. Oxford: IRL Press.

Baylis, H. A. \& Bibb, M. J. (1988a). Organization of the ribosomal RNA genes in Streptomyces coelicolor A3(2). Mol $\mathcal{E}$ Gen Genet 211, 191-196.

Baylis, H. A. \& Bibb, M. J. (1988b). Transcriptional analysis of the 16S rRNA gene of the $r r n D$ gene set of Streptomyces A3(2). Mol Microbiol 2, 569-579.

Berg, K. L., Squires, C. \& Squires, C. L. (1989). Ribosomal RNA operon anti-termination. Function of leader and spacer region box B-box A sequences and their conservation in diverse microorganisms. J Mol Biol 209, 345-358. 
Birnboim, H. C. \& Doly, J. (1979). A rapid alkaline extraction procedure for screening recombinant plasmid DNA. Nucleic Acids Res 7, 1513-1523.

Boros, I., Csordás-Tóth, E., Kiss, A., Török, I., Udvardy, K. \& Venetianer, P. (1983). Identification of two new promoters probably involved in the transcription of a ribosomal RNA gene of Escherichia coli. Biocbim Biophys Acta 739, 173-180.

Brosius, J., Dull, D. J., Sleeter, D. D. \& Noller, H. F. (1981). Gene organization and primary structure of a ribosomal RNA operon from Escherichia coli. J Mol Biol 148, 107-127.

Dewhirst, F. E., Paster, B. J., La Fontaine, S. \& Rood, J. I. (1990). Transfer of Kingella indologenes (Snell and Lapage 1976) to the genus Suttonella gen. nov. as Suttonella indologenes comb. nov.; transfer of Bacteroides nodosus (Beveridge 1941) to the genus Dicbelobacter gen. nov. as Dichelobacter nodosus comb. nov.; and assignment of the genera Cardiobacterium, Dichelobacter, and Suttonella to Cardiobacteriaceae fam. nov. in the gamma division of Proteobacteria based on 16S ribosomal ribonucleic acid sequence comparisons. Int I Syst Bacteriol 40, 426-433.

Felsenstein, J. (1989). PHYLIP - Phylogeny Inference Package (Version 3.2). Cladistics 5, 164-166.

Finkel, S. E. \& Johnson, R. C. (1992). The FIS protein: it's not just for DNA inversion anymore. Mol Microbiol 6, 3257-3265.

Friedman, D. I. \& Gottesman, M. (1983). Lytic mode of lambda development. In Lambda II, pp. 21-52. Edited by R. Hendrix, J. Roberts, F. Stahl \& R. Weisburg. Cold Spring Harbor, NY: Cold Spring Harbor Laboratory

Gaal, T., Rao, L., Estrem, S. T., Yang, J., Wartell, R. \& Gourse, R. L. (1994). Localization of the intrinsically bent DNA region upstream of the E. coli rrnB P1 promoter. Nucleic Acids Res 22, 2344-2350.

Garnier, T., Canard, B. \& Cole, S. T. (1991). Cloning, mapping and molecular characterization of the rRNA operons of Clostridium perfringens. J Bacteriol 173, 5431-5438.

Gill, S., Bell-Isles, J., Brown, G., Gagné, S., Lemieux, C., Mercier, J.P. \& Dion, P. (1994). Identification of variability of ribosomal DNA spacer from Pseudomonas soil isolates. Can J Microbiol 40, 541-547.

Gish, W. \& States, D. J. (1993). Identification of protein coding regions by database similarity search. Nature Genetics 3, 266-272.

Gutell, R. R. (1992). Evolutionary characteristics of $16 \mathrm{~S}$ and $23 \mathrm{~S}$ rRNA structures. In The Origin and Evolution of the Cell, pp. 243-309. Edited by H. Hartman \& K. Matsuno. River Edge, NJ: W'orld Scientific Publishing.

Hahn, J., Inamine, G., Kozlov, Y. \& Dubnau, D. (1993). Characterization of comE, a late competence operon of Bacillus subtilis required for the binding and uptake of transforming DNA. Mol Microbiol 10, 99-111.

Hobbs, M., Dalrymple, B. P., Cox, P. T., Livingstone, S. P., Delaney, S. F. \& Mattick, J. S. (1991). Organization of the fimbrial gene region of Bacteroides nodosus: class I and class II strains. Mol Microbiol 5, 543-560.

Hobbs, M., Collie, E. S. R., Free, P. D., Livingston, S. P. \& Mattick, J. S. (1993). PilS and PilR, a two-component transcriptional regulatory system controlling expression of type 4 fimbriae in Pseudomonas aeruginosa. Mol Microbiol 7, 669-682.

Jinks-Robertson, S. \& Nomura, M. (1987). Ribosomes and tRNA. In Escherichia coli and Salmonella typhimurium: Molecular and Ceilular Biology, pp. 1358-1385. Edited by F. C. Neidhardt, J. L. Ingraham, K. B. Low, B. Magasanik, M. Schaechter \& H. E. Umbarger. Washington, DC: American Society for Microbiology.

Katz, M. E., Howarth, P. M., Yong, W. K., Riffkin, G. G., Depiazzi, L. J. \& Rood, J. I. (1991). Identification of three gene regions associated with virulence in Dichelobacter nodosus, the causative agent of ovine footrot. J Gen Microbiol 137, 2117-2124.

Katz, M. E., Wright, C. L., Gartside, T. S., Cheetham, B. F., Doidge, C. V., Moses, E. K. \& Rood, J. I. (1994). Genetic organization of the duplicated vap region of the Dichelobacter nodosus genome. J Bacteriol 176, 2663-2669.

Keller, G. H. \& Manak, M. M. (1989). DN A Probes. New York: M. Stockton Press.

Krawiec, S. \& Riley, M. (1990). Organization of the bacterial chromosome. Microbiol Rev 54, 502-539.

Kustu, S., Santero, E., Keener, J., Popham, D. \& Wiess, D. (1989). Expression of $\sigma 54(n \operatorname{tr} \mathrm{A})$-dependent genes is probably united by a common mechanism. Microbiol Rev 53, 367-376.

La Fontaine, S. \& Rood, J. I. (1990). Evidence that Bacteroides nodosus belongs in subgroup gamma of the class Proteobacteria, not in the genus Bacteroides: partial sequence analysis of a B. nodosus $16 \mathrm{~S} \mathrm{rRNA}$ gene. Int J Syst Bacteriol 40, 154-159.

La Fontaine, S., Egerton, J. R. \& Rood, J. I. (1993). Detection of Dichelobacter nodosus using species-specific oligonucleotides as PCR primers. Vet Microbiol 35, 101-117.

Loughney, K., Lund, E. \& Dahlberg, J. E. (1982). tRNA genes are found between the $16 \mathrm{~S}$ and $23 \mathrm{~S}$ rRNA genes in Bacillus subtilis. Nucleic Acids Res 10, 1607-1624.

Maidak, B. L., Larsen, N., McCaughey, M. J., Overbeek, R., Olsen, G. J., Fogel, K., Blandy, J. \& Woese, C. R. (1994). The ribosomal database project. Nucleic Acids Res 22, 3485-3487.

Menke, M. A. O. H., Liesack, W. \& Stackebrandt, E. (1991). Ribotyping of $16 \mathrm{~S}$ and $23 \mathrm{~S}$ rRNA genes and organization of rrn operons in members of the bacterial genera Gemmata, Planctomyces, Thermotoga, Thermus and Verrucomicrobium. Arch Microbiol 155, 263-271.

Miller, J. H. (1972). Experiments in Molecular Genetics. Cold Spring Harbor, NY: Cold Spring Harbor Laboratory.

Minnick, M. F., Strange, J. C. \& Williams, K. F. (1994). Characterization of the 16S-23S rRNA spacer of Bartonella bacilliformis. Gene 153, 149-150.

Nakagawa, T., Uemori, T., Asada, K., Kato, I. \& Harasawa, R. (1992). Acholeplasma laidlawii has tRNA genes in the $16 \mathrm{~S}-23 \mathrm{~S}$ spacer of the rRNA operon. $J$ Bacteriol 174, 8163-8165.

Morelle, G. (1989). A plasmid extraction procedure on a miniprep scale. Focus 11, 7-8.

Nomura, M., Morgan, E. A. \& Jaskunas, S. R. (1977). Genetics of bacterial ribosomes. Annu Rev Genet 11, 297-347.

Pearson, W. R. \& Lipman, D. J. (1988). Improved tools for biological comparison. Proc Natl Acad Sci US A 85, 2444-2448.

Pérez-Martín, J., Rojo, F. \& de Lorenzo, V. (1994). Promoters responsive to DNA bending: a common theme in prokaryotic gene expression. Microbiol Rev 58, 268-290.

Reizer, A., Deutscher, J., Saier, M. H. \& Reizer, J. (1991). Analysis of the gluconate (gnt) operon of Bacillus subtilis. Mol Microbiol 5, 1081-1089.

Rosenberg, M. \& Court, D. (1979). Regulatory sequences involved in the promotion and termination of RNA transcription. Annu Rev Genet 13, 319-353.

Sambrook, J., Fritsch, E. F. \& Maniatis, T. (1989). Molecular Cloning: a Laboratory Manual. Cold Spring Harbor, NY: Cold Spring Harbor Laboratory.

Skerman, T. M. (1975). Determination of some in vitro growth requirements of Bacteroides nodosus. J Gen Microbiol 87, 107-119.

Smith, C. L. \& Cantor, C. R. (1987). Purification, specific frag- 
mentation and separation of large DNA molecules. Methods Enzymol 155, 449-467.

Southern, E. M. (1975). Detection of specific sequences among DNA fragments separated by gel electrophoresis. $J$ Mol Biol 98, 503-517.

Specht, T., Wolters, J. \& Erdmann, V. A. (1990). Compilation of $5 \mathrm{~S}$ rRNA and $5 S$ rRNA gene sequences. Nucleic Acids Res 18 (Supplement), 2215-2230.

Squires, C. L., Pederson, S., Ross, B. M. \& Squires, C. (1991). ClpB is the Escherichia coli heat shock protein F84.1. J Bacteriol 173, 4254-4262.

Srivastava, A. K. \& Schlessinger, D. (1989). Processing pathway of Escherichia coli $16 \mathrm{~S}$ precursor rRNA. Nucleic Acids Res 17, 16491663.

Srivastava, A. K. \& Schlessinger, D. (1990). Mechanism and regulation of bacterial ribosomal RNA processing. Annu Rev Microbiol 44, 105-129.

Stewart, D. J. (1989). Footrot of sheep. In Footrot and Foot Abscess of Ruminants, pp. 5-45. Edited by J. R. Egerton, W. K. Yong \& G. G. Riffkin. Boca Raton, FL: CRC Press.

Takamiya, M., Salazar, O., Vargas, D., Jedlicki, E. \& Orellana, O. (1990). Identification and structural analysis of a ribosomal RNA gene promoter from Thiobacillus ferrooxidans. FEBS Lett 272, $50-54$.

Thomas, J. H. (1958). A simple medium for the isolation and cultivation of Fusiformis nodosus. Aust Vet J 34, 411.

Tinoco, I., Jr, Borer, P. N., Dengler, B., Levine, M. D., Uhlenbeck, O. C., Crothers, D. M. \& Gralla, J. (1973). Improved estimation of secondary structure in ribonucleic acids. Nature 246, 40 41.

Wagner, R. (1994). The regulation of ribosomal RNA synthesis and bacterial cell growth. Arch Microbiol 161, 100-109.

Wang, R. F. \& Kushner, S. R. (1991). Construction of versatile lowcopy-number vectors for cloning, sequencing and gene expression in Eschericbia coli. Gene 100, 195-199.

Yanisch-Perron, C., Vieira, J. \& Messing, J. (1985). Improved M13 cloning vectors and host strains: nucleotide sequences of the M13mp18 and pUC19 vectors. Gene 33, 103-119.

Zhang, S. \& Nonoyama, M. (1994). The cellular proteins that bind specifically to the Epstein-Barr virus origin of plasmid DNA replication belong to a gene family. Proc Natl Acad Sci USA 91, 2843-2847.

Received 22 May 1995; revised 21 November 1995; accepted 27 November 1995. 